\title{
REKAYASA MESIN PENGUPAS KULIT BUAH KOPI JENIS ROBUSTA MODEL TEP-JLL 2015 DI KABUPATEN TANA TORAJA
}

\author{
Design of Pulper Machine Model Tep-Jll 2015 for Fresh Coffee Robusta in Tana Toraja \\ Jois L. Langi ${ }^{1)^{*}}$, Daniel P. M. Ludong2), Lady C. Ch. E. Lengkey ${ }^{2)}$ \\ ${ }^{1)}$ Mahasiswa Program Studi Teknik Pertanian \\ ${ }^{2)}$ Dosen Program Studi Teknik Pertanian \\ Jurusan Teknologi PertanianFakultas Pertanian, \\ Universitas Sam Ratulangi Manado \\ *e-mail : joiskhing@gmail.com
}

\begin{abstract}
The objective of this research was to design a pulper machine model TEPJLL 2015 for fresh coffee robusta used in rural areas of Tana Toraja district. The machine was designed based on the analysis of physical characteristics of Robusta Tana Toraja coffee and literature study. The analysis result of physical characteristics showed the average length, thickness width was $12.494 \mathrm{~mm}, 12.802 \mathrm{~mm}, 10.687 \mathrm{~mm}$, respectively, and the bulk density was $1,115 \mathrm{~kg} / \mathrm{m}^{3}$. The theoretical hopper capacity of this machine was 3.7687 $\mathrm{kg}$. Assuming the cylinder speed was $111.594 \mathrm{rpm}$ with an effective distance setting system or flawed setting of $1.2 \mathrm{~cm}$, the theoretical capacity of this pulper machine was $380.62 \mathrm{~kg} /$ hour.
\end{abstract}

Keywords: fresh Robusta coffee fruit, pulper machine

\section{PENDAHULUAN}

Kopi merupakan minuman favorit masyarakat Indonesia, baik dari kalangan atas, menengah sampai kalangan bawah, baik pria maupun wanita. Dari berbagai daerah di Indonesia kopi mempunyai ciri khas dan cita rasa serta ukuran yang beraneka ragam, tidak terkecuali di daerah Tana Toraja yang merupakan salah satu daerah penghasil kopi di Indonesia. Jenis kopi yang dihasilkan adalah jenis kopi Toraja Arabika dan kopi Toraja Robusta dengan buah yang berwarna coklat tua saat matang dan bentuk biji yang tidak beraturan.

Menurut Direktorat Jenderal Perkebunan (2011), areal perkebunan kopi di Indonesia pada tahun 2010 mencapai lebih dari 1,210 juta hektar dengan total produksi sebesar 686.921 ton dimana $96 \%$ diantaranya yaitu areal perkebunan kopi rakyat, dengan jumlah petani yang terlibat sebanyak 1.881.694 KK. Laju perkembangan areal kopi di Indonesia rata - rata mencapai sebesar $2,11 \%$ per tahun.

Untuk produksi kopi di Kabupaten Toraja Utara dikutip dari Tribun Toraja.com, *luas lahan areal perkebunan kopi mencapai 5.572,63 hektar dengan produksi sebanyak 4.468,83 ton, sedangkan produksi kopi di Kabupaten Tana Toraja untuk tahun 2016 mencapai 3.889.9 ton dengan luas lahan 1.278,2 hektar (Badan Pusat Statistik Tana Toraja, 2016). Jadi untuk jumlah produksi keseluruhan untuk kopi Toraja mencapai 4.857,82 ton dengan luas lahan mencapai 
5.700,45 hektar. *Sumber : Kepala Dinas Kehutanan dan Perkebunan Toraja Utara, 2016.

Sedangkan untuk konsumsi kopi di Indonesia berdasarkan Pusat Data dan Sistem Informasi Pertanian Kementerian Pertanian konsumsi kopi nasional pada 2016 mencapai sekitar 250 ribu ton dan tumbuh 10,54\% menjadi 276 ribu ton. Konsumsi kopi Indonesia sepanjang periode 2016 sampai 2021 nanti diprediksi tumbuh rata-rata 8,22\%/tahun. Pada 2021 nanti, pasokan kopi diprediksi mencapai 795 ribu ton dengan konsumsi 370 ribu ton, sehingga terjadi surplus 425 ribu ton.

Berdasarkan data dari International Coffee Organization (ICO) pada tahun 2016 sampai saat ini, Indonesia menduduki peringkat keempat dalam daftar penghasil kopi terbanyak di dunia setelah Brazil, Vietnam, dan Colombia. Berdasarkan data yang dilansir oleh ICO, dunia ini telah memproduksi sekitar 9 juta ton kopi. Negara Indonesia menghasilkan jumlah produksi sebanyak 600 ribu ton kopi. Sedangkan negara Brazil menghasilkan jumlah produksi sekitar 3,3 juta ton atau sekitar $36 \%$ dari jumlah produksi kopi dunia ini.

Sebagai salah satu penghasil kopi terbanyak di dunia, pengolahan kopi di Indonesia harus lebih diperhatikan terutama dibagian pengupasan kulit buah kopi. Pengupasan kulit buah kopi sendiri adalah bagian dari proses pengolahan kopi menjadi produk (bubuk) yang siap untuk dipasarkan. Pengupasan dilakukan dengan berbagai cara diantaranya menggunakan mesin dengan cara buah kopi dimasukkan kedalam mesin pengupas kemudian mesin akan secara otomatis mengupas buah kopi untuk memisahkan kulit dan biji. Sedangkan cara tradisional adalah cara yang paling sederhana yang umumnya dilakukan oleh petani di pedesaan contohnya di daerah Tana Toraja di wilayah pedesaan dimana pengupasan dilakukan dengan cara buah kopi yang telah matang akan dimasukan kedalam suatu wadah (Issong) dan ditumbuk menggunakan sebatang kayu besar (Alu) dengan tujuan biji dan kulit akan terpisah. Namun cara ini dapat merusak biji kopi sehingga perlu adanya rekayasa mesin pengupas kulit buah kopi.

Berdasarkan masalah yang ada maka diperlukan sebuah inovasi yaitu merekayasa sebuah mesin pengupas kulit buah kopi yang memiliki sistem pengatur celah pengupasan yang nantinya diharapakan rekayasa mesin pengupas kulit buah kopi ini dapat dijadikan sebagai acuan untuk membuat mesin pengupas yang lebih efektif dan efisien untuk digunakan di Kabupaten Tana Toraja khususnya di wilayah pedesaan.

Pengupasan kulit buah kopi menggunakan mesin pengupas berlangsung didalam celah diantara permukaan silinder yang berputar (rotor) dan permukaan plat atau pisau yang diam (stator). Rotor memiliki permukaan yang bertonjolan atau bergelembung (buble plate) yang dibuat dari bahan logam lunak sejenis tembaga (Sri-Mulato et al., 2006; Wintgens, 2004). Untuk putaran silinder pengupas pada sebuah mesin pengupas yang ideal adalah $110 \mathrm{rpm}$ (Sodik dkk, 2016), semakin besar ukuran sebuah slinder pengupas maka rpm dari silinder tersebut akan lebih lambat dikarenakan apabila rpm silinder pengupas terlalu cepat akan terjadi kerusakan baik pada mesin maupun biji kopi yang dihasilkan. Umumnya proses pengupasan kulit buah kopi (pulping process) dibantu oleh sejumlah air yang dilakukan secara mekanis baik dengan sumber tenaga penggerak manual maupun dengan motor listrik atau motor bakar. Mburu (1995) menyarankan dilakukan pemisahan buah kopi sebelum pengolahan. Namun, kegiatan pemisahan berdasarkan ukuran akan berdampak pada waktu proses bertambah lama dan peningkatan biaya proses baik dari aspek penyediaan alsin 
maupun tenaga kerjanya

\section{METODE PENELITIAN}

\section{Tempat dan Waktu Penelitian}

Penelitian ini dilakukan di Laboratorium Keteknikan bagian Alat dan Mesin Pertanian yang telah berlangsung pada bulan Juli 2019 sampai bulan April 2020.

\section{Alat dan Bahan}

Alat perancang yang digunakan, meteran, las listrik, kunci inggris, obeng, gerinda, bor listrik, penitik, tang, garis penyiku, roll tap (forming tap). Alat tulis menulis dan software pembuat desain yang digunakan, pensil, penghapus, mistar dan software sketchup versi 2017. Alat pengukur yang digunakan, stopwatch, tachometer, dan neraca.

Bahan perancang yang digunakan, besi kotak, besi siku, besi plat, pipa pvc, besi baja bulat, v-belt, puli v-belt, dan pillow block. Bahan percobaan yang digunakan adalah Buah kopi Toraja jenis Robusta seberat $20 \mathrm{~kg}$ dengan umur panen 9-10 bulan yang didatangkan langsung dari kecamatan Rembon dan Sanggalla, kabupaten Tana Toraja.

\section{Metode Penelitian}

Metode yang digunakan dalam penelitian ini adalah metode rancangan atau design mesin pengupas dalam bentuk gambar teknik, kemudian membuat atau membangun berdasarkan desain yang telah dibuat secara nyata. Metode rancang bangun juga berdasarkan analisis pendekatan ciri khas buah kopi Robusta Tana Toraja (uji karakteristik fisik) dan studi pustaka.

Cacatan : Pembuatan mesin pengupas kulit buah kopi belum sampai tahap uji coba yang kemudian dihentikan karena pandemi covid-19 secara global termasuk di Indonesia.

\section{Tahapan Peneltian}

Tahapan dalam penelitian ini terbagi atas 4 bagian yaitu :

1. Desain yaitu menggambar desain mesin pengupas menggunakan software sketchup versi 2017

2. Pembuatan komponen penyusun yaitu membuat bagian dari setiap komponen penyusun sehingga menghasilkan rancangan nyata dari gambar desain yang sudah dibuat.

3. Studi kepustakaan/literatur dilakukan untuk melengkapi data atau informasi sebagai referensi berdasarkan penelitian-penelitian yang telah dilakukan oleh penelti sebelumnya.

4. Perhitungan kinerja mesin pengupas adalah perhitungan kinerja dari mesin pengupas kulit buah kopi (kapasitas pengupasan teoritis) berdasarkan data yang didapatkan di lapangan dan ditambahkan dengan studi kepustakaan (data sekunder).

Diagram alir cara pembuatan mesin pengupas buah kopi :

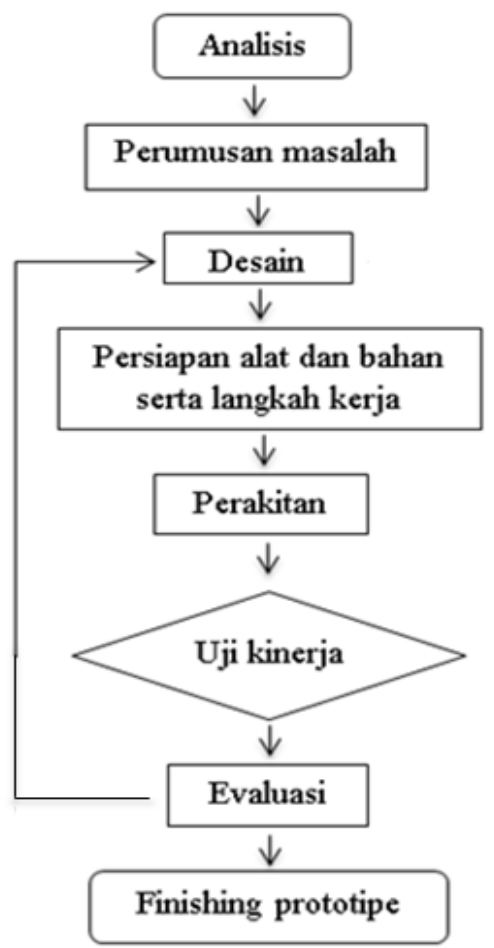

Diagram alir diatas menjelaskan tahapan dalam proses pembuatan mesin 
pengupas kulit buah kopi dimana yang pertama adalah analisis yaitu menguraikan hal-hal yang terjadi dalam proses pengupasan kulit buah kopi. Tahap kedua adalah perumusan masalah yaitu merumuskan masalah yang ditemui dalam penelitian ini. Tahap ketiga desain yaitu menggambar desain mesin pengupas kulit buah kopi menggunakan software sketchup. Tahap keempat persiapan alat dan bahan yaitu mempersiapkan semua bahan perancang dan alat perancang yang dibutuhkan untuk kemudian diukur, dilubangi, dipotong, maupun direkatkan sehingga membentuk suatu komponen penyusun. Dalam tahap persiapan alat dan bahan perancang akan ditentukan langkah cara kerja yang akan digunakan misalnya membuat komponen penyusun yang paling utama atau yang akan disusun pertama kalinya seperti membuat komponen rangka utama yang nantinya komponen penyusun ini akan menjadi penopang dari seluruh kompoenen mesin. Tahap kelima perkitan yaitu semua komponen penyusun direkatkan atau disatukan sehingga membentuk atau mencipatakan desain nyata dari gambar yang telah ada (mesin pengupas kulit buah kopi).

Pada tahap keenam uji kinerja atau uji coba yaitu mesin pengupas akan diuji kinerjanya secara kasar. Tahap ketujuh yaitu evaluasi dimana mesin pengupas akan diukur kembali kinerjanya menggunakan beberapa parameter, jika mesin masih belum efisien maka akan dilakukan perbaikan pada bagian tertentu pada mesin yang dimulai dari perbaikan desain gambar kemudian memperbiaki mesin pengupas secara langsung berdasarkan perbaikan desain gambar yang telah ada. Kemudian tahap paling akhir yaitu finishing prototipe adalah tujuan akhir dari rekayasa mesin pengupas kulit buah kopi jenis Robusta dari Tana Toraja

\section{Hal-hal yang Diamati}

Bahan percobaan (Buah kopi) :

a. Rata-rata panjang, lebar dan tebal

b. Densitas kamba (bulk density)

c. Persentase hasil kupasan per kilogram

d. Kapasitas penampungan (hopper).

\section{Perhitungan Kinerja Mesin}

Mesin pengupas kulit buah kopi :

a. Rpm puli $\mathrm{N}_{1}$ sampai $\mathrm{N}_{6}$

b. Kapasitas pengupasan teoritis.

\section{Metode Perhitungan}

1. Bahan percobaan (Buah kopi) :

a. Rata-rata panjang, lebar dan tebal (uji laboratorium)

b. Densitas kamba (bulk density)

Rumus yang digunakan (Idhansyah, 2019) :

$\rho b=\frac{w b}{v}$

Dimana :

$\rho b:$ Bulk density (Densitas kamba buah kopi) (gram $\left./ \mathrm{cm}^{3}\right)$

$w b$ : Berat buah kopi pada wadah (gram)

$v$ : Volume wadah $\left(\mathrm{cm}^{3}\right)$

c. Persentase hasil kupasan per kilogram (uji laboratorium)

d. Kapasitas penampungan (hopper).

Rumus yang digunakan :

$V p=l a \times t p$

$l a=\frac{\text { jumlah sisi sejajar }}{2} \times t p$

Dimana :

$V p$ : Volume $\left(\mathrm{cm}^{3}\right)$

la : Luas alas $\left(\mathrm{cm}^{2}\right)$ atau luas dinding hopper

tp : Tinggi Trapesium $(\mathrm{cm})$ atau panjang hopper

Jadi kapasitas atau daya tampung massa hopper dapat dihitung dengan persamaan sebagai berikut :

$K h=V p x \rho b$

Dimana :

$K h$ : Kapasitas tampung (gr)

$V p$ : Volume hopper (m3) 
$\rho b$ : Densitas kamba (gr/cm3)

2. Mesin pengupas kulit buah kopi :

a. Menghitung putaran puli (RPM)

Menghitung rpm dari masingmasing puli (N1, N2 ,N3, N4, N5, dan N6) dengan asumsi tidak adanya slip.

Perhitungan ini berdasarkan rpm ideal yaitu 110 rpm (Sodik dkk, 2016) yang mendekati atau hampir sama dengan rpm tersebut.

Rumus yang digunakan (Rokhman, 2014) :

Diketahui : rpm puli $N 1=1400 \mathrm{rpm}$ (motor penggerak)

$N 2=\frac{N 2}{N 1}=\frac{D 1}{D 2}$

Rpm puli N3 dan rpm puli N2 sama dikarenakan kedua puli berputar pada poros yang sama atau kedua puli berputar pada kecepatan sudut yang sama (Angular velocity).

$N 4=\frac{N 4}{N 3}=\frac{D 3}{D 4}$

Rpm puli N5 dan rpm puli N4 sama dikarenakan kedua puli berputar pada poros yang sama atau kedua puli berputar pada kecepatan sudut yang sama (Angular velocity).

$N 6=\frac{N 6}{N 5}=\frac{D 5}{D 6}$

Dimana :

$\mathrm{N}=$ Rotasi per menit (rpm)

$\mathrm{D}=$ diameter pulley $(\mathrm{cm})$

b. Perhitungan kinerja mesin

Rumus yang digunakan (Tambun, 1996) :

$K P T=\frac{D t \times \text { Vpe } \times D k}{T}$

Dimana :

KPT : Kapasitas Pengupasan Teoritis $\quad[(\mathrm{kg} /$ detik atau $\mathrm{kg} / \mathrm{jam})]$

Dt $\quad: \mathrm{Da} \times \mathrm{Db}$
Da: Faktor buah menggelinding dalam celah pengupasan

$D b$ : Faktor dimensi untuk 1 kali muatan pengupasan

Vpe : Volume ruang pengupasan efektif $\left(\mathrm{m}^{3}\right)$

Rumus yang digunakan untuk mencari Vpe :

$$
\text { Vpe }=\text { Cp } \times \text { Ps } x \text { Lp }
$$

Dimana :

$C p$ : Celah atau jarak pengupasan efektif (m)

$P s$ : Panjang silinder dan plat pengupas $(\mathrm{m})$

$L p$ : Lebar pengupasan efektif (m)

Rumus yang digunakan untuk mencari $L p$ :

$L p=\frac{D p e}{360} \times \mathrm{kl}$

Dimana :

Dpe: Derajat Pengupasan efektif $\left({ }^{\circ}\right)$

360 : Derajat 1 putaran penuh lingkaran/silinder $\left(^{\circ}\right)$

$K l \quad$ : Keliling lingkaran/silinder (m)

$D k$ : Densitas kamba buah kopi $\left(\mathrm{kg} / \mathrm{cm}^{3}\right)$

$T$ : Waktu satu putaran silinder (detik) $T=\frac{1}{N S} \times 60 \mathrm{detik} / \mathrm{menit}$

$N S$ : Rotasi per menit silinder pengupas (rpm).

\section{HASIL DAN PEMBAHASAN}

Rekayasa mesin pengupas kulit buah kopi dalam penelitian ini telah mempunyai sistem pengatur bukaan plat pengupas yang berfungsi untuk mengatur jarak antara plat pengupas dan silinder pengupas. Mesin ini juga mempunyai slinder pipa pada bagian hopper yang berfungsi mendorong dan menyalurkan buah kopi kedalam bagian pengupasan 
(Gambar 3.). Pada bagian bawah plat pengupas terdapat sistem roda plat pengupas yang bergerak maju mundur dan berfungsi sebagai tumpuan bagian bawah plat pengupas dan juga berfungsi mengatur jarak antara plat pengupas dan silinder pengupas (Gambar 2.). Ukuran tinggi keseluruhan dari rekayasa mesin ini adalah $90 \mathrm{~cm}$ dengan lebar $62 \mathrm{~cm}$ dan panjang $63 \mathrm{~cm}$. (Gambar 1.)

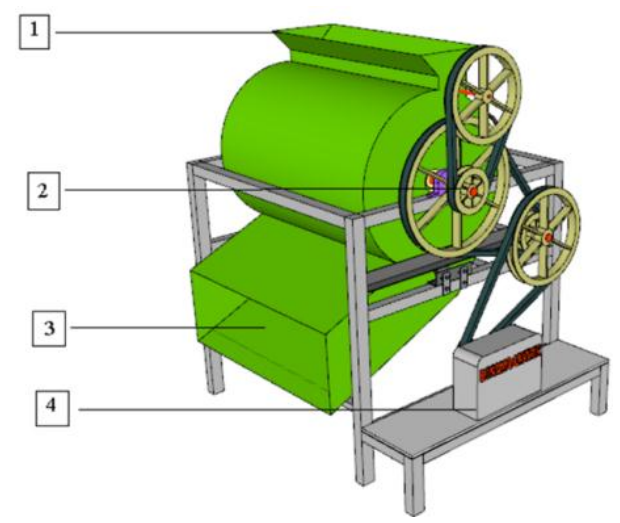

Gambar 1. Mesin Pengupas buah kopi model TEP-JLL 2015

Keterangan :

1. Penampungan Buah Kopi (Hopper)

2. V-belt dan Puli V-belt

3. Saluran Keluar Biji Kopi

4. Motor Penggerak

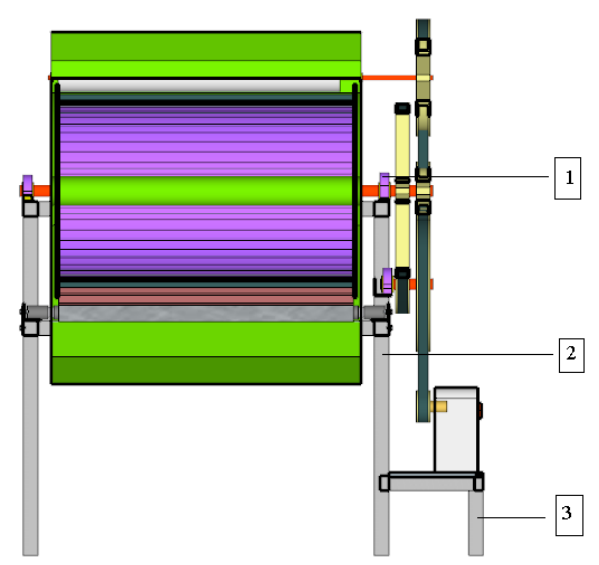

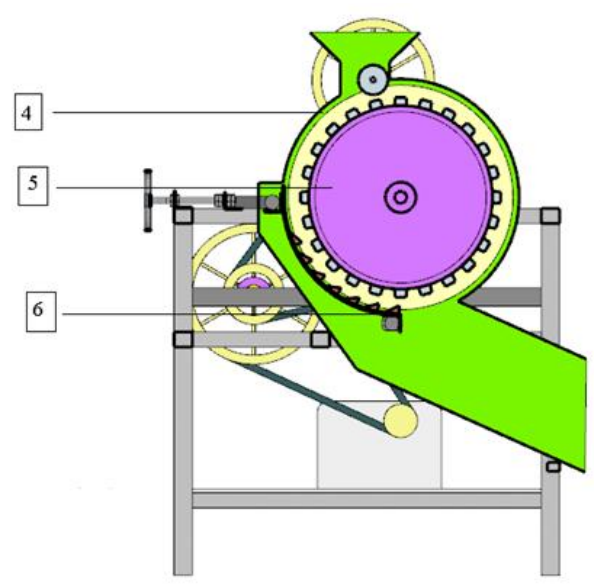

Gambar 2. Bagian-bagian Mesin Pengupas buah kopi

Keterangan :

1. Pillow Block

2. Rangka Utama

3. Rangka Penopang Motor Penggerak

4. Casing

5. Silinder Pengupas

6. Plat Pengupas dan sistem roda plat pengupas

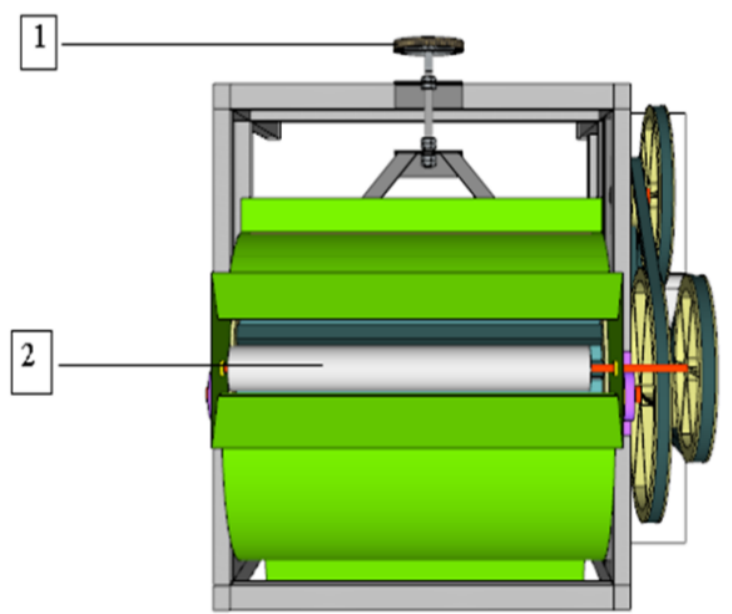

Gambar 3. Sistem Pengatur celah pengupas dan Silinder pemasukkan buah kopi

Keterangan :

1. Sistem Pengatur Bukaan Plat Pengupas

2. Silinder Pipa 


\section{Hasil Pengamatan}

\section{Buah kopi}

Pengukuran rata-rata ukuran buah kopi mulai dari panjang, lebar, dan tebal dilakukan dengan tujuan untuk menentukan jarak ideal yang akan digunakan pada celah antara silinder pengupas dan plat pengupas.

Berdasarkan hasil pengukuran di laboratorium maka didapatkan hasil sebagai berikut (Tabel 1) :

Tabel 1. Ukuran rata-rata buah kopi

\begin{tabular}{lcrr}
\hline & $\begin{array}{c}\text { Panjang } \\
(\mathbf{m m})\end{array}$ & $\begin{array}{r}\text { Lebar } \\
(\mathbf{m m})\end{array}$ & $\begin{array}{r}\text { Tebal } \\
(\mathbf{m m})\end{array}$ \\
\hline Max & 15,94 & 14,99 & 16.87 \\
Min & 8,76 & 3,14 & 8,46 \\
\hline Rata-rata & 12,494 & 10,687 & 12,802 \\
\hline
\end{tabular}

1. Densitas kamba

Perhitungan densitas kamba buah kopi (bulk density) yaitu perbandingan antara berat buah kopi pada gelas ukur terhadap volume gelas ukur dengan tujuan untuk dapat mengetahui perancangan pada bagian penampungan buah kopi (hopper).

Hasil perhitungan di laboratorium dengan ukuran gelas ukur $500 \mathrm{ml}$ atau 0,5 liter, bahwa dalam $500 \mathrm{ml}$ atau 0,5 liter jumlah buah kopi rata-rata pada gelas ukur terdapat 311 butir. Berat buah kopi didapatkan rata-rata 557,6667 gram atau $0,5576 \mathrm{~kg}$ serta volume gelas ukur 500 $\mathrm{cm}^{3}$ atau $0,0005 \mathrm{~m}^{3}$, maka didapatkan bulk density (densitas kamba buah kopi) yaitu $1,115 \mathrm{gram} / \mathrm{cm}^{3}$ atau $1.115 \mathrm{~kg} / \mathrm{m}^{3}$.

\section{Persentase hasil kupasan}

Pengukuran rata-rata hasil kupasan dilakukan untuk mengetahui berat biji kopi hasil kupasan dan mengetahui berat yang hilang setelah kulit buah kopi terkelupas. Hasil pengukuran akan menjadi pembanding pada perhitungan kapasitas pengupasan teoritis.

Berdasarkan pengukuran rata-rata hasil kupasan buah kopi didapatkan bahwa $1 \mathrm{~kg}$ buah setelah dikupas menjadi biji kopi maka beratnya akan berkurang menjadi 680,75 gram atau dengan persentase berat $68,08 \%$. Hasil perhitungan juga menunjukkan jumlah butir rata-rata buah kopi $1 \mathrm{~kg}$ sebanyak 795 butir, sedangkan jumlah butir rata-rata biji kopi hasil kupasan sebanyak 1345 butir dengan persentase kehilangan berat setelah kulit buah kopi terkelupas $31,93 \%$.

\section{Kapasitas penampungan (hopper)}

Berdasarkan data hasil perhitungan densitas kamba buah kopi didapatkan $1,115 \mathrm{gram} / \mathrm{cm}^{3}$ atau $1.115 \mathrm{~kg} / \mathrm{m}^{3}$ serta volume penampungan (hopper) dengan luas alas prisma trapesium atau luas dinding penampungan (hopper) $65 \mathrm{~cm}^{2}$ dan tinggi prisma atau panjang penampung (hopper) $52 \mathrm{~cm}$ diperoleh volume penampungan $3380 \mathrm{~cm}^{3}$ atau $0,00338 \mathrm{~m}^{3}$, maka kapasitas penampungan (hopper) adalah :

$3380 \mathrm{~cm}^{3} x 1,115 \mathrm{gram} / \mathrm{cm}^{3}=3.768,7$ gram atau $3,7687 \mathrm{~kg}$

Jadi, dengan dimensi penampungan (hopper) sebesar $3380 \mathrm{~cm} 3$ ini dapat menampung 3.768,7 gram ( $3,7687 \mathrm{~kg})$ dan dengan jumlah buah kopi utuh ratarata sebanyak 5425 butir.

\section{Perhitungan Kinerja Mesin}

\section{Menghitung putaran puli (RPM)}

Perhitungan rpm dilakukan dengan tujuan untuk memenuhi kriteria atau mendekati rpm yang ideal yaitu $110 \mathrm{rpm}$ dengan asumsi tidak adanya slip (Gambar 4.). 


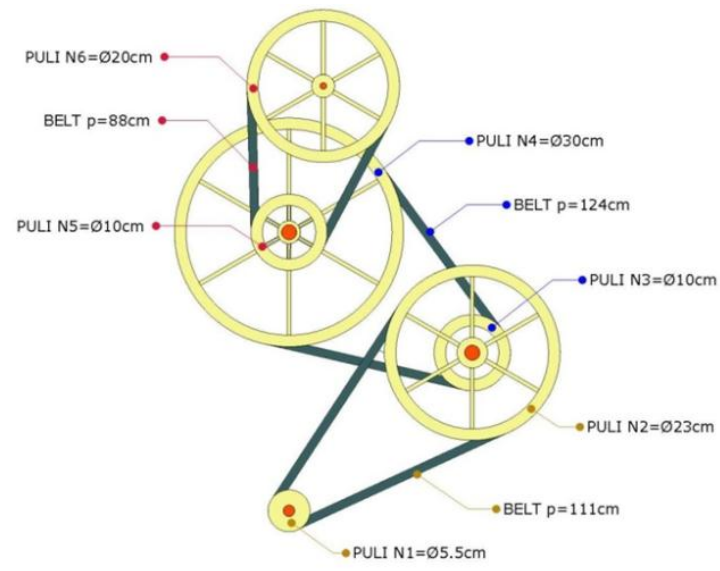

Gambar 4. Sistem Transmisi Daya, Puli dan V-belt serta Diameter Puli

Hasil perhitungan :

$$
\begin{aligned}
& \mathrm{N}_{1}=1400 \mathrm{rpm} \\
& \mathrm{N}_{2}=>\frac{N 2}{N 1}=\frac{D 1}{D 2} \\
& \mathrm{~N}_{2}=>\frac{N 2}{1400 \mathrm{rpm}}=\frac{5,5 \mathrm{~cm}}{23 \mathrm{~cm}} \\
& \mathrm{~N}_{2}=\left(\frac{5,5 \mathrm{~cm}}{23 \mathrm{~cm}}\right) \times 1400 \mathrm{rpm}=334,782
\end{aligned}
$$

rpm

Rpm puli $\mathrm{N}_{3}$ dengan rpm puli $\mathrm{N}_{2}$ sama dikarenakan kedua puli berputar pada poros yang sama (Angular velocity). Rpm puli $\mathrm{N}_{3}$ yaitu 334,782 rpm.

$$
\begin{aligned}
& \mathrm{N}_{4}=>\frac{N 4}{N 3}=\frac{D 3}{D 4} \\
& \mathrm{~N}_{4}=>\frac{N 3}{334,783 \mathrm{rpm}}=\frac{10 \mathrm{~cm}}{30 \mathrm{~cm}} \\
& \mathrm{~N}_{4}=\left(\frac{10 \mathrm{~cm}}{30 \mathrm{~cm}}\right) \times 334,782 \mathrm{rpm}= \\
& 111,594 \mathrm{rpm}
\end{aligned}
$$

Rpm puli $\mathrm{N}_{5}$ dengan rpm puli $\mathrm{N}_{4}$ sama dikarenakan kedua puli berputar pada poros yang sama (Angular velocity). Rpm puli $\mathrm{N}_{5}$ yaitu 111,594 rpm.

$$
\begin{aligned}
& \mathrm{N}_{6}=>\frac{N 6}{N 5}=\frac{D 5}{D 6} \\
& \mathrm{~N}_{6}=>\frac{N 6}{334,783 \mathrm{rpm}}=\frac{10 \mathrm{~cm}}{20 \mathrm{~cm}} \\
& \mathrm{~N}_{6}=\left(\frac{10 \mathrm{~cm}}{20 \mathrm{~cm}}\right) \times 111,594 \mathrm{rpm}=55,797 \\
& \mathrm{rpm}
\end{aligned}
$$

2. Perhitungan kapasitas pengupasan teoritis :
Rumus yang digunakan :

$K P T=\frac{D t \times V p e x D k}{T}$

Dimana :

KPT : Kapasitas Pengupasan Teoritis [(kg/detik atau $\mathrm{kg} / \mathrm{jam})]$

Dt $: D a \times D b=0,17 \times 0,33=0,516$

$D a$ :Faktor asumsi buah menggelinding dalam celah pengupasan $(\mathrm{Da}=0,17)$

$D b$ :Faktor dimensi untuk 1 muatan pengupasan diasumsikan membutuhkan 3 kali ulangan $(\mathrm{Db}=0,33)$

Vpe : Volume ruang pengupasan efektif $\left(\mathrm{m}^{3}\right)$

$D k \quad$ : Densitas Kamba buah kopi $\left(\mathrm{kg} / \mathrm{m}^{3}\right)$

$T$ : Waktu satu putaran silinder (detik)

Penyelesaian :

$V p e=C p \times L p \times P S$

Dimana :

$\mathrm{Cp}$ : celah atau jarak pengupasan efektif $=1,2 \mathrm{~cm}$ atau $0,012 \mathrm{~m}$

$P S$ : Panjang silinder dan plat pengupas $=50 \mathrm{~cm}$ atau $0,5 \mathrm{~m}$

Lp : Lebar pengupasan efektif $=$ $0,2224 \mathrm{~m}$ $L p=\frac{75}{360} \times K l$

Dimana :

$\mathrm{Kl}$ : Keliling lingkaran/silinder $(\mathrm{m})$ $\mathrm{Kl}: 2 \times 3,14 \times 0,17 \mathrm{~m}=1,0676 \mathrm{~m}$ Derajat efektif pengupasan : $75^{\circ}$ $360^{\circ}$ atau 1 putaran penuh lingkaran/silinder

$L p=\frac{75}{360} \times 1,0676=0,2224 \mathrm{~m}$

Vpe $=0,012 \mathrm{~m} \times 0,5 \mathrm{~m} \times 0,2224 \mathrm{~m}=$ $0,001334 \mathrm{~m}^{3}$

$D k=1115 \mathrm{~kg} / \mathrm{m}^{3}$

$T=\frac{1 \mathrm{put}}{111,594 \mathrm{put} / \text { menit }} \times 60 \mathrm{det} / \mathrm{menit}=$ 0,537 detik

Jadi, kapasitas pengupasan teoritis : $K P T=\frac{0,0516 \times 0,001334 \mathrm{~m} 3 \times 1115 \mathrm{~kg} / \mathrm{m} 3}{0,537 \mathrm{det}}=$ $0,1553 \mathrm{~kg} /$ detik atau 559,08 $\mathrm{kg} / \mathrm{jam}$ (masih dalam bentuk buah). 
Hasil perhitungan kapasitas pengupasan teoritis didapatkan 0,1553 $\mathrm{kg} /$ detik atau 559,08 $\mathrm{kg} / \mathrm{jam}$. Hasil ini akan dikalikan dengan persentase hasil kupasan biji per kilogram 68,08 \% dan didapatkan hasil sebagai berikut :

$0,1553 \times 68,08 \%=0,1057 \mathrm{~kg} /$ detik $559,08 \mathrm{~kg} x 68,08 \%=380,62 \mathrm{~kg} / \mathrm{jam}$

\section{KESIMPULAN}

1. Hasil rekayasa mesin pengupas kulit buah kopi dengan menggunakan dinamo listrik sebagai motor penggerak ini terdiri dari beberapa komponenkomponen penyusun diantaranya adalah rangka utama, v-belt, puli vbelt, silinder pengupas, as silinder pengupas, silinder pipa, as silinder pipa, penampungan (hopper), pillow block, plat pengupas, pengatur bukaan plat pengupas, sistem roda plat pengupas, dan casing. Ukuran mesin pengupas kulit buah kopi jenis Robusta secara keseluruhan yaitu panjang 63 $\mathrm{cm}$, lebar $62 \mathrm{~cm}$, dan tinggi $90 \mathrm{~cm}$.

2. Hasil uji laboratorium pada buah kopi jenis Robusta dari Tana Toraja untuk mesin pengupas kulit buah kopi sebagai berikut :

a. Ukuran rata-rata buah kopi adalah sebagai berikut : panjang 12,494 $\mathrm{mm}$, tebal $12,802 \mathrm{~mm}$, dan lebar $10,687 \mathrm{~mm}$.

b. Densitas kamba (bulk density) buah kopi yaitu $1,115 \mathrm{gram} / \mathrm{cm}^{3}$ atau $1.115 \mathrm{~kg} / \mathrm{m}^{3}$.

c. Volume penampungan (hopper) yaitu $3380 \mathrm{~cm}^{3}$ dapat menampung buah kopi seberat 3.768,7 gram atau $3,7687 \mathrm{~kg}$.

3. Hasil perhitungan kinerja mesin pengupas kulit buah kopi sebagai berikut :

a. Hasil perhitungan kecepatan putaran (Rpm) dari masing-masing puli dengan asumsi tidak ada slip adalah sebagai berikut : Kecepatan putaran motor penggerak (N1) $1400 \mathrm{rpm}$, silinder pengupas (N4) : 111,594 rpm dan silinder pengumpan/ pemasukan pada penampungan (hopper) : 55,797 rpm.

b. Kapasitas teoritis pengupasan buah kopi jenis Robusta Tana Toraja adalah $0,1553 \mathrm{~kg} /$ detik atau 559,08 $\mathrm{kg} / \mathrm{jam}$ (masih dalam bentuk buah). Hasil dikalikan dengan persentase hasil kupasan biji per kilogram (rendemen) 68,08 \% maka didapatkan hasil biji kopi sebesar $0,1057 \mathrm{~kg} /$ detik atau 380,62 kg/jam.

\section{DAFTAR PUSTAKA}

Badan Pusat Statistik Kabupaten Tana Toraja 2016. Luas (Ha) dan Produksi (Ton) Tanaman Perkebunan Menurut Kecamatan dan Jenis Tanaman di Kabupaten Tana Toraja, $2011-2015$.

https://tatorkab.bps.go.id/statictable/20 15/06/23/15/luas-ha-produksiton-tanaman-perkebunanmenurut-kecamatan-dan-jenistanaman-di-kabupaten-tanatoraja-2011---2015.html. Diakses tanggal 24 Maret 2019. Idhansyah. 2019. Rancang Bangun dan Uji Teknis Alat Tanam Jagung (Zea mays L.) Tipe TP CSM 15 Dengan Menggunakan Traktor Tangan Sebagai Alat Penarik. Skripsi Fakultas Pertanian. Universitas Sam Ratulangi Manado. Sulawesi Utara.

Mburu. J. K. Notes On Coffee Processing Procedures and their influence On quality. Kenya Coffee, 60, 21312136.

Parlin Tambun. 1996. Mempelajari Perbaikan Alat Pengupas Kacang Tanah Bertenaga Mesin TETA M61. Manado. Skripsi Fakultas Pertanian. Universitas Sam 
Ratulangi Manado. Sulawesi Utara.

Sekertariat Direktorat Jenderal Perkebunan, Direktorat Jenderal Perkebunan , Kementrian Pertanian. 2016. Statistik Perkebunan Kopi Indonesia Tahun 2015 - 2017.

http://ditjenbun.pertanian.go.id/tinymc puk/gambar/file/statistik/2017/ Kopi-2015-2017.pdf. Diakses tanggal 24 Maret 2019.

Sodik. A, K. Suharno \& Widodo. S. 2016. Perancanngan Mesin Pengupas Kopi Menggunakan Dua Rol Pengupas. Fakultas Teknik Universitas Tidar Magelang. Jawa Tengah.

Sri-Mulato; S. Widyotomo \& E. Suharyanto. 2006. Teknologi Proses dan Pengolahan Produk Primer dan Sekunder Kopi. Pusat Penelitian Kopi dan Kakao Indonesia. Jember, Jawa Timur.

Taufiqur Rokhman. 2014. Menghitung Daya Transmisi dan Efisiensi. https://taufiqurrokhman.wordpr ess.com/2014/02/10/menghitun g-daya-transmisi-dan-efisiensi/. Diakses tanggal 30 Mei 2020.

Tribun Toraja.com 2016. Kopi Toraja Utara, Sulawesi Selatan.

http://makassar.tribunnews.com/2016/0 2/29/produksi-kopi-torajautara-andalan-sulsel-inialasannya. Diakses tanggal 25 Maret 2019.

Wintgens. J. N. 2004. Coffee : Growing Processing, Sustainable Production. A Guidebook for Growes, Processors, Traders, dan Researches. Wiley-VCH Verlag $\mathrm{GmbH} \&$ Co. KgaA. Weinheim. Wurtemberg. Jerman. 